\title{
Effects of fermented coffee on human gut microbiota
}

\author{
Gwangpyo Ko ${ }^{1}$ (D) $\cdot$ Jin-Kyeong $\mathrm{Kim}^{2} \cdot$ Seong-Wha $\mathrm{Jo}^{2} \cdot$ Do-Youn Jeong ${ }^{2} \cdot$ \\ Tatsuya Unno ${ }^{1}$
}

\section{발효커피가 사람장내미생물에 미치는 영향}

\author{
고광표 $^{1} \cdot$ 김진경 ${ }^{2} \cdot$ 조숭화 $^{2} \cdot$ 정도연 $^{2} \cdot$ 운노 타쯔야 $^{1}$
}

Received: 29 January 2020 / Accepted: 28 February 2020 / Published Online: 31 March 2020

(C) The Korean Society for Applied Biological Chemistry 2020

\begin{abstract}
Fermented foods have been recognized as functional foods that provide health benefits, including the modulation of intestinal microbiota. Therefore, the aim of the present study was to examine the effects of coffee beans fermented with Lactobacillus plantarum and Bacillus amyloliquefaciens on healthy human gut microbiota. Fermentation increased the content of beneficial substances (i.e., flavonoids and polyphenols). The consumption of fermented coffee increased the occurrence of beneficial microorganisms such as fiber degraders and short-chain fatty acid producers, although no significant microbiota shifts were observed after the coffee consumption. The analysis of metabolic activities also showed no difference after the coffee consumption. Our study demonstrates that the consumption of the fermented coffee may increase some beneficial bacterial while remaining the gut microbiota and its activities.
\end{abstract}

Keywords Fermented coffee - Functional food · Human gut microbiota $\cdot$ Microbial community analysis

Tatsuya Unno $(\square)$

E-mail: tatsu@jejunu.ac.kr

${ }^{1}$ Faculty of Biotechnology, School of life sciences, SARI Jeju National University, Jeju 63243, Republic of Korea

${ }^{2}$ Microbial Institute for Fermentation Industry (MIFI), Sunchang, Jeonbuk 595804, Republic of Korea

This is an Open Access article distributed under the terms of the Creative Commons Attribution Non-Commercial License (http://creativecommons. org/licenses/by-nc/3.0/) which permits unrestricted non-commercial use, distribution, and reproduction in any medium, provided the original work is properly cited.

\section{서 론}

2006년 미국 Health잡지가 뽑은 세계인 건강식품 5가지 중 3가 지가 발효 식품이며 최근에 발효과정에 의한 생리활성 작용이 알려지면서 발효식품이 세계적으로 건강 기능성 식품으로 인식 되고 있다[1]. 미생물들은 오래 전부터 발효 유제품을 중심으로 각종 장류, 김치, 발효소시지, 의약품 및 가축의 사료 첨가제에 이르기 까지 그 특성에 따라 인류의 생활에 직·간접적으로 밀 접한 관계를 맺고 있다[2,3]. 발효된 식품은 기존의 식품보다 풍 미가 높고 미생물 생육억제물질인 bacteriocin을 생성하여 항균 활성을 지니며 다량의 젖산을 생성하여 식품 내의 부패균 성장 을 억제하는 역할을 한다[4]. 이전연구에서는 발효식품중하나인 요커트를 섭취하여 cardiovascular disease, type 2 diabetes로 인한 사망률이 감소했다는 보고가 있다[5-7]. 이러한 이유로 몇 몇의 사람들은 발효식품을 국가적인 식단 권고사항의 일부로 포 함시켜야 한다고 제안했다[8].

커피는 커피 생두를 가공한 다음 추출한 음료이며 세계적으 로 가장 널리 음용되고 있는 기호식품 중의 하나로 자리를 잡 았다. 커피는 다른 식품에 비해 폴리페놀 등의 항산화성분 함 량이 높아 세포 손상을 유발하는 자유라디칼 소거능이 높다고 알려져 있다 [9,10]. 커피 발효는 coffee cherry를 발효 하는 것 으로 알려져 있으며, 건조과정 이전에 coffee beans을 감싸고 있 는 mucilage layer를 효과적으로 제거하여 기능성을 높이기 위 해서가 아닌 순수한 coffee beans을 얻는 것에 목표를 두고 있 다[11]. 그러나 이전 연구에서 2차공정과정에 yeast를 사용해 커 피를 발효함으로써 폴레페놀과 플라보노이드 같은 항산화물질 을 증가시켰다 보고되어있다[12]. 즉, 커피는 2차공정 과정에서 발효를 통해 기능성을 높일 수 있다. 이러한 결과를 바탕으로 발효미생물 산업 진흥원(Sunchang, Korea)에서 안전한 식품미 생물인 Lactobacillus spp.와 Bacillus spp.를 이용하여 커피를 발효함으로써 발효커피를 개발하여 상품화 하였다. 이에따라 본 
연구는 발효미생물 산업 진흥원에서 개발한 발효커피가 발효전 과의 차이점과 인체에 적용하여 일반적인 생활에서 발효커피에 의한 장내미생물 생태 변화를 객관적으로 평가하고자 한다.

\section{재료 및 방법}

\section{발효커피 제조 공정}

커피생두(Brazil, Colombia, Costarica, Kenya)는 우성엠에프 (Hwaseong, Korea)에서 구입하였다. 커피생두와 물을 $1: 1.5$ 의 비율로 1 시간 동안 침지과정을 거친 후 $121^{\circ} \mathrm{C}, 1$ 시간 동안 증 자과정을 진행하였다. 그 후, cool-down과정을거쳐 Bacillus amyloliquefaciens SRCM101368, Lactobacillus plantarum $\mathrm{SRCM} 100320$ 2종을 커피생두에 접종하여 $37^{\circ} \mathrm{C}, 24$ 시간 동안 발효과정을 진행하였다. 브라질 생두는 B. amyloliquefaciens를 이용해 발효하였으며, 콜롬비아, 코스타리카, 케냐 생두는 $L$. plantarum을 이용해 발효하였다. 발효 후 수세과정을 거쳐 열풍 건조기 $45^{\circ} \mathrm{C}, 24$ 시간 동안 건조하였다. 발효커피의 혼합비율은 Table $\mathrm{S} 1$ 와 같다.

\section{시료 추출 및 준비}

발효커피는 열풍건조기에 $45^{\circ} \mathrm{C}$ 에서 $24 \mathrm{~h}$ 건조를 한 후 분말화 하여 $80 \%$ 에탄올에 10 배 희석한 후 $40{ }^{\circ} \mathrm{C}, 180 \mathrm{rpm}$ 에서 $4 \mathrm{~h}$ 추출하였다. 추출액은 0.45 실린지 필터를 이용하여 잔사를 제 거한 후 여액을 실험 시료로 사용하였다.

\section{생균수 측정}

생균수는 시료를 멸균생리식염수에 순차적으로 10 배수로 희석 하여 NA, MRS media에서 도말, $37^{\circ} \mathrm{C}$ 에서 1 일간 배양 한 후 colony를 계수하여 측정하였다.

\section{총 폴리페놀, 플라보노이드 함량 및 DPPH radical 소거능 측정} 총 페놀 함량은 Folin-Denis 방법에 따라 추출된 시료 $200 \mu \mathrm{L}$ 에 Folin-Ciocalteu reagent $12.5 \mu \mathrm{L}$ 를 혼합하여 교반한 뒤, 120 분 동안 상온에서 방치하여 반응시켰으며 UV-Vis spectrophotometer (DU 800, Beckman coulter, Fullerton, CA, USA) 를 사용하여 $750 \mathrm{~nm}$ 에서 분석하였다. 총 플라보노이드 함량은 Davis 방법에 따라 추출된 시료를 $0.5 \mathrm{~mL}$ 에 $10 \%$ aluminum nitrate $0.1 \mathrm{~mL}, 1 \mathrm{M}$ potassium acetate $0.1 \mathrm{~mL}$ 및 ethanol 4.3 $\mathrm{mL}$ 를 차례로 가하여 혼합한 후 상온에서 $40 \mathrm{~min}$ 방치하여 반 응시켜 $450 \mathrm{~nm}$ 에서 흡광도를 측정하였다. 1,1-diphenyl-2picrylhydrazyl (DPPH) 라디칼 소거능은 Blois의 방법을 변형하 여 전자공여작용 (electron donationg abilities)에 대한 효과로 각 시료의 환원력을 측정하였다. 즉, 시료 $50 \mu \mathrm{L}$ 에 $0.15 \mathrm{mM}$ $\mathrm{DPPH}$ solution (99\% Methanol에 용해) $150 \mu \mathrm{L}$ 을 가한 후 30 $\min$ 상온에서 방치한 후 분광광도계를 사용하여 흡광도 $517 \mathrm{~nm}$ 에서 흡광도의 변화를 측정하였다.

\section{임상실험 디자인}

본 연구는 제주대학교 생명윤리위원회(IRB)의 승인을 받아 진 행하였다(JJNU-IRB-2017-035-002). 본 연구에 관한 IRB승인 후, 평소에 커피를 자주 섭취하는 피험자 10 명(남: 5 명, 여: 5 명)을
모집하였다. 임상실험은 총 4주 동안 수행하였으며, 2주차씩 나 누어 진행하였다. 즉 1-2주 기간에는 발효커피를 섭취하지 않으 며, 3-4주 기간에는 피험자들에게 발효커피를 하루 2잔 이상씩 섭취하도록 하였다. 발효커피를 섭취하는 기간에는 발효커피 이 외의 다른 커피 섭취를 금지하도록 하였다.

임상실험에 참여한 피험자들은 참여기간 전에 당뇨병, 고혈 압, 암, 이상지질혈증 등과 같은 질병이 없었으며, 실험참여기 간 동안에는 장내미생물생태에 영향을 미칠 수 있는 약물, 술, 건강 보조제, 자극적인 음식 등의 섭취가 금지 되었다. 발효커 피를 섭취하는 3-4주 기간을 제외한 나머지 기간에는 일반커피 섭취를 허용하였다.

\section{분변 채취 및 DNA 추출}

본 실험은 장내미생물생태 분석에 사용하기 위해 각 피험자는 분변을 OMNIgene-Gut kit OMR-200 (DNA Genotek, Ontario, Canada) 을 사용하여 발효커피 섭취전날과 섭취 마지막날 분변 을 채취하도록 하였다. 수집된 분변은 채취 후 2 일 이내에 실 험실로 보내도록 하였으며, 받는 즉시 MOBIO Power Fecal DNA isolation kit (MO BIO Laboratories Inc., Carlsbad, CA, $\mathrm{USA}$ )를 사용하여 용액에 녹아있는 대변 $200 \mu \mathrm{L}$ 에서 총 DNA 를 추출 하였다.

\section{$16 \mathrm{~S}$ rRNA 유전자 시퀀싱}

장내미생물생태 분석을 위해 $16 \mathrm{~S} \mathrm{rRNA}$ 유전자내의 과변부위 (Variable region) 중 V4 region을 Polymerase Chain Reaction (PCR)통해 증폭하였으며[13], 2-step PCR을 통해 일루미나시퀀 싱(Illumina sequencing) platform 중 하나인 Miseq platform $(250 \mathrm{bp} \times 2)$ 에 맞춰 library를 제작하였다. 즉, 1 차 $\mathrm{PCR}$ 은 $\mathrm{KAPA}$ HiFi HotStart ReadyMix PCR kit (Roche, Wilmington, MA, $\mathrm{USA}$ )를 사용하였으며, $\mathrm{PCR}$ 반응 조건은 $95^{\circ} \mathrm{C}$ 에서 3 분간 초기 열처리한 후, $95^{\circ} \mathrm{C}$ 에서 30 초, $55^{\circ} \mathrm{C}$ 에서 30 초, $72^{\circ} \mathrm{C}$ 에서 30 초 간씩 25 회 반복하고, 마지막에는 $72{ }^{\circ} \mathrm{C}$ 에서 5 분 반응 시켰다. PCR 산물은 HiAccuBead (AccuGene, Incheon, Korea)로 정제 하였다. 정제된 $\mathrm{PCR}$ 산물은 다시 $\mathrm{PCR}$ 을 이용하여 샘플 식별 을 위한 barcode-sequencing을 진행하였으며, 2차 PCR후 생성 된 $\mathrm{PCR}$ 산물을 전에 설명한 동일한 방식으로 정제 하였다. 최 종 PCR 산물은 Qubit (Invitrogen Inc., Carlsbad, CA, USA) 으로 농도를 측정하였으며, 동일한 농도로 모아 Miseq 시퀀싱 (sequencing) 수행을 위해 마크로젠(Seoul, Repulic of Korea)에 의뢰하였다. 시퀀싱 결과는 fastq 파일형태로 받았으며, 미국 국 립생물정보센터(Bethesda, MD, USA)에서 운영하는 Sequence Read Archive에 등록하였다 (BioProject: PRJNA544370).

\section{장내미생물생태분석}

MiSeq으로부터 얻은 시퀀스데이터는 MOTHUR 소프트웨어를 이용하여 오류 제거 및 통계분석을 수행하였다[14]. Operational taxonomic units (OTU)는 MOTHUR opti.clust[15]를 이용하여 $97 \%$ 유사성으로 계산되었으며, 각 OTU는 Ribosome database project (version 16) 속 수준까지 분류되었다. 샘플 간 거리는 통계방법 중 하나인Bray-curtis 방법으로 계산되었으며, MOTHUR 의 "tree.shared" 명령어를 사용하여 시각화 하였다. 그룹 간 유 의한 차이가 있는 OTUs는 MOTHUR의 Linear discriminant 
analysis Effect Size (LEfSe)를 사용하여 조사하였으며[16], 샘 플 간 유의적 차이가 있는 상관관계는 non-metric multidimensional scaling (NMDS) plot으로 나타내었다[17]. 또한 PICRUSt2 (Phylogenetic Investigation of Communities by Reconstruction of Unobserved States 2)를 이용하여 16S rRNA 유전자 기반 metabolic pathway를 추정하였다[18].

\section{통계분석}

통계학적 분석은 $\mathrm{ANOVA}$ 를 사용하여 유의성검정을 실시하였고, 유의성이 있을때 사후검정으로 Tukey's HSD를 사용하였다 $(p<0.05)$. Analysis of molecular variance (AMOVA)는 NMDS plot에서 그룹 간 유의한 차이를 조사하기 위해 사용되었다. PICRUSt2를 통한 metabolic pathway의 유의한 차이는 STAMP (Statistical analysis of metagenomics profiles) 소프트웨어 상의 Welch's t-test기반으로 수행하였다[19].

\section{결과 및 고찰}

\section{생균수 측정}

발효커피의 생균수를 측정한 결과는 Table S2와 같다. 모든 생 두에서 $10^{6} \mathrm{CFU} / \mathrm{g}$ 에서 $24 \mathrm{~h}$ 발효 후 $10^{8} \sim 10^{9} \mathrm{CFU} / \mathrm{g}$ 까지 증가 하였다. 따라서 고초균과 유산균이 커피생두를 이용하여 발효되 었음을 확인할 수 있었다.

\section{총 폴리페놀, 플라보노이드 함량 및 DPPH radical 소거능 측정} 발효에의한 커피원두내의 생리활성 및 전자공여능을 조사하기 위해 총 폴리페놀, 플라보노이드 및 항산화 활동을 측정하였다. 그 결과 커피원두를 발효함으로써 항산화 활성 뿐만아니라 폴 리페놀 및 플라보노이드와 같은 유익한 물질의 양을 현저히 증 가하였음을 확인 하였다(Fig. 1). 항산화 활성은 기능성식품의 중요한 역할 중 하나이며, 플라보노이드는 인간의 장내에서 잠 재적 병원균인 Clostridia를 감소시킨다고 보고되어 있다[20]. 또
한, 블루베리에서 추출한 폴리페놀이 고지방식이를 섭취한 비만 생쥐에서 장내미생물생태를 변화시켜 항비만 효과를 갖는다 보 고되어 있다[21]. 이러한 결과는 발효커피가 인간의 장내에서 유 익한 물질을 증가시킬 수 있는 잠재력을 가지고 있음을 시사한다.

\section{장내미생물생태분석}

발효커피를 섭취전과 섭취 후의 장내미생물생태 차이를 조사하 였다. 총 10 명의 피험자를 모집하였으며, 피험자들의 생리학적 특성은 Table S3에 요약하였다. 장내미생물생태 비교를 위해 분 변으로부터 얻어진 DNA로부터 전처리 후 가장작은 염기서열 개수인 27,780reads로 맞추어 모든 샘플을 표준화시켰다. 10명 의 피험자의 장내미생물생태는 총 2가지 Cluster로 분류되었다 (Fig. S1). 하나의 그룹은 피험자 Q (BMI: 21.9)를 제외하고 상 대적으로 높은 BMI를 갖는 Cluster였으며 (BMI: 25.7-29.4; A, $\mathrm{D}, \mathrm{E}$, and $\mathrm{O}$ ), 반면 다른 그룹은 피험자 $\mathrm{G}$ (BMI: 28.7)를 제 외하고 상대적으로 낮은 $\mathrm{BMI}$ 를 갖는 Cluster임을 확인하였다 (BMI: 19.6-24.5: I, K, R and T). 속(Genus) 수준에서의 relative abundance를 Heatmap으로 나타내었다(Fig. S2). Prevotella-type의 피험자는 $\mathrm{A}, \mathrm{G}, \mathrm{I}, \mathrm{K}, \mathrm{R}$ 및 $\mathrm{T}$ 였으며, Bacteroides-type의 피험 자는 $\mathrm{D}, \mathrm{E}, \mathrm{O}$ 및 $\mathrm{Q}$ 임을 확인하였다. Prevotella와 Bacteroides 의 비율은 체중감량과 연관되어있다고 보고되어있다[22], 즉 Prevotella-type의 피험자들이 식단 조절을 통해 체중감량에 성 공할 가능성이 더 높다는 것을 시사한다. 장내미생물의 종 다 양성(Richness)을 나타내는 Chao와 종 균등성(Evenness)을 나타 내는 Inv-Simpson 및 Shannon지표를 발효커피를 섭취전과 후 로 나누어 비교해보았다(Fig. 2). 그 결과 발효커피를 섭취함으 로써 종 균등성은 유의한 차이가 없음을 확인하였으나, 종의 풍 부함은 크게 증가했음을 확인 할 수 있었다.

발효커피 섭취로인한 미생물군집의 변화는 AMOVA와 NMDS 를 통해 분석하였다. NMDS상에서 발효커피 섭취로인한 미생 물군집의 변화는 유의적인 차이가 없었지만, LEfSe를 통한 분 석에서 발효커피섭취 전후 유의적인 차이를 보이는 6개의 OTU 를 확인하였다(Fig. 3). 발효커피 섭취로인하여 Alistipes spp.,
(A)

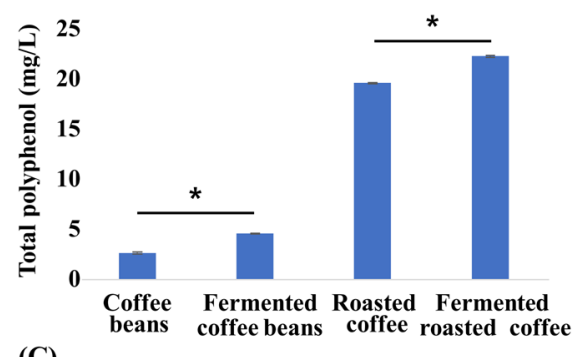

(C)

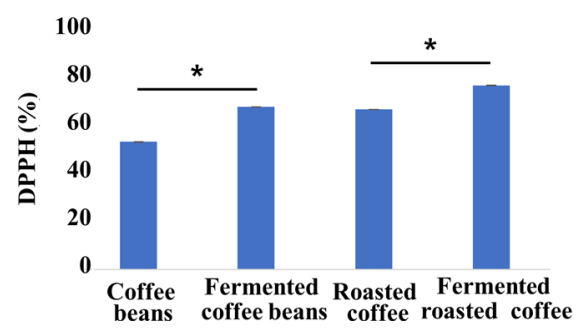

(B)

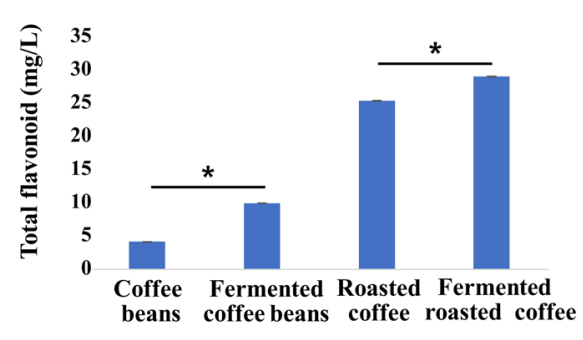

Fig. 1 Effects of fermentation of coffee: (A) Total polyphenol (mg/L); (B) total flavonoid (mg/L); (C) DPPH radical scavenging activity (\%); * indicate $p<0.05$ with the student's T-test 



Fig. 2 Ecological indices comparison, species evenness comparison with inverted Simpson (A) and Shannon (B) and species richness with Chao (C); * indicate $p<0.05$ with the student's T-test

(A)

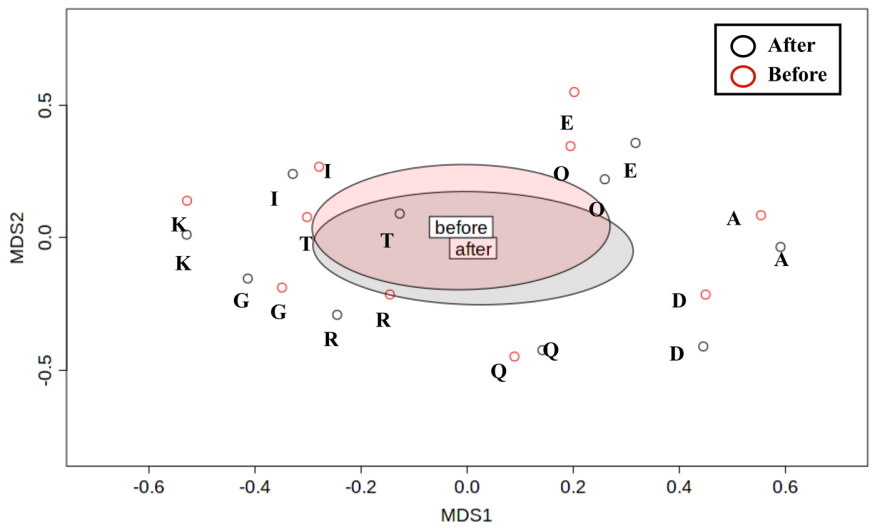

(B)

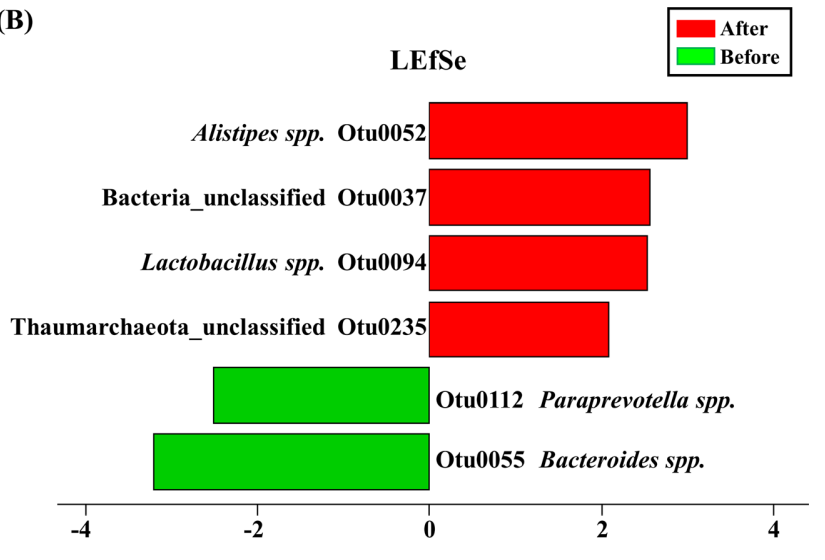

Fig. 3 Microbial community comparison based on non-metric multidimensional scaling (A) and Linear discriminant analysis Effect Size (B)

Lactobacillus spp., unclassified Bacteria 및 Archea의 abundance 가 현저히 증가한 반면, Paraprevotella spp. 및 Bacteroides spp.의 abundance는 현저히 감소하였다. Alistipes spp.는 인간의 장내에서 이로운 물질인 Butyrate를 생성하는 미생물로 알려져 있으며[23] Lactobacillus spp.는 인간의 장내에서 이로운 물질 인 Lactic acid를 생성하는 대표적인 프로바이오틱스로 알려져 있다. Paraprevotella spp.는 비만 및 고혈압과 관련되어있다고 보고되어 있다[24,25]. 종합적으로 이러한 결과는 발효커피를 섭 취함으로써 인간의 건강에 이로운 효과를 가져올수 있음을 시 사하며, 정확한 효과를 확인하기 위해 생리학적 차이를 추가로 조사할 필요가있다. 마지막으로, 발효커피 섭취에따른 미생물의 물질대사 변화를 조사해본 결과 9개의 metabolic pathways를 제 외하고는 유의적인 차이가 없음을 확인하였다(Fig. S3). KEGG database를 참고하여 선별되어진 pathways의 역할은 다음과 같다. EC:1.14.14.1 (Unspecific monooxygenase)는 caffeine metabolism 과정에 관여하며, oxidoredutases class에 포함되어 있다. EC: 1.2.4.4 (3-methyl-2-oxobutanoate dehydrogenase) 또한 oxidoredutases class에 포함되어 있으며, propionate metabolism 과정에 관여한
다. EC:6.4.1.6 (Acetone carboxylase)는 acetate 생산과 관련되 어 있으며, EC:4.1.99.14 (Spore photoproduct lyase)는 DNA 복구 과정과 관련되어 있다. 특히 EC:2.4.1.58 (glycosyltransferase), $\mathrm{EC}: 2.6 .1 .92$ (transaminase) 및 EC:3.2.1.82 (galacturonosidase) 는 glucose metabolisms 과정에 관여될 수 있으며, EC:3.4.21.110 (peptidase) 및 EC:1.13.11.27 (dioxygenease)는 peptides와 amino acids 같은 작은 분자의 metabolism 과정에 관여한다. 따라서 발 효커피 섭취는 energy metabolisms을 향상시킬 것으로 사료된 다. 또한 EC:1.13.11.27 (4-hydroxyphenylpyruvate dioxygenase) 는 병리학적으로 Type III tyrosinemia와 직접적으로 연관되어 있다. 간단히 말하면 4-hydroxyphenylpyruvate dioxygenase 물 질은 혈액 내 타이로신을 분해한다. 즉, 이 물질이 결핍되면 혈 액내의 타이로신의 농도가 높아져 가벼운 정신지체를 갖는 신 생아 출생 확률이 높아지며, 더 나아가 나이가 들수록 시력이 저하된다[26]. 이러한 관점에서 발효커피는 Type III tyrosinemia 환자에게 이로운 효과를 줄 것이라 기대되며, 이에 대한 실질 적인 평가와 이외 다른 metabolic pathways가 인간의 건강에 미치는 영향을 확인하기 위해 추가적인 실험이 필요하다. 
본 연구에서 발효에 의해 커피원두내 총 폴리페놀과 총 플라 보노이드의 양을 조사하였다. 비록 시간에 따른 함량을 조사하 지 못하였지만 발효에 의해 커피원두 내 총 플라보이드와 총 폴리페놀 함량이 증가하였으며, 발효 시간에 따른 이 물질들의 함량을 조사하여 본다면 발효시간 단축 개선에 큰 도움이 될 것이라 사료된다. 또한 발효커피 섭취로 인해 장내미생물생태 및 미생물에 의한 물질대사의 유의미한 변화는 관찰하지 못하 였지만, Lactobacillus spp.와 Alistipes spp. 같은 유익균은 증가 하였으며, Paraprevotella spp.와 같은 유해균은 감소하였다. 이 러한 결과로 발효커피의 장기간 섭취는 인간의 장내에 유익한 미생물을 증가시켜 건강을 증진시킬 것으로 사료된다.

\section{초 록}

발효식품은 장 건강을 포함하여 건강상의 이로운점을 제공하는 건강기능식품으로 인식되고 있다. 따라서 본 연구는 Lactobacillus plantarum과 Bacillus amyloliquefaciens로 발효 된 커피원두가 건강한 사람의 장내미생물 생태에 미치는 영향을 조사하였다. 커피원두를 발효하여 플라보노이드와 폴리페놀과 같은 이로운 물질이 증가하였다. 또한 발효커피의 섭취로 인해 유의한 장내 미생물생태 및 물질대사 변화가 관찰되지 않았지만, 섬유소 분 해 및 단쇄지방산을 생성하는 유익한 미생물이 증가하였다. 본 연구 결과는 발효커피 섭취로인해 장내미생물생태 및 물질대사 를 유지하면서 유익한 미생물이 증가하였음을 확인하였다.

Keywords 기능성 식품·미생물생태분석·발효커피·장내미생물

감사의 글 본 논문은 농림축산식품부 지역 전략 식품산업 육성사업(과제명 : 동부권 고기능 토종발효미생물과 향토자원을 이용한 발효제품 개발 및 기 능성 분석)의 연구비지원으로 이루어졌으며, 이에 감사드립니다. 이 논문은 2019학년도 제주대학교 교원성과지원사업에 의하여 연구되었습니다.

\section{References}

1. Park K-Y (2012) Increased health functionality of fermented foods. J Korean Soc Food Sci Nutr 17.1 (2012): 1-8

2. Kim J-H, Lee W-J, Cho Y-W, Kim K-Y (2009) Storage-life and palatability extension of Betula platyphylla sap using lactic acid bacteria fermentation. J Korean Soc Food Sci Nutr 38: 787-794

3. Hong SW, Lim IK, Kim YW, Shin S-M, Chung KS (2013) Denaturing gradient gel electrophoresis and culture-based analysis of the bacterial community in Cheonggukjang, a Korean traditional fermented soybean food from Gangwon province. Korean J Food Sci Technol 45: 515-520

4. Matsumura H, Takeuchi A, Kano Y (1997) Construction of Escherichia coli ${ }^{\circ} \mathrm{CB}$ Bifidobacterium longum shuttle vector transforming B. longum 105-A and 108-A. Biosci Biotech Bioch 61: 1211-1212

5. Chen M, Sun Q, Giovannucci E, Mozaffarian D, Manson JE, Willett WC, Hu FB (2014) Dairy consumption and risk of type 2 diabetes: 3 cohorts of US adults and an updated meta-analysis. BMC Med 12: 215

6. Tapsell LC (2015) Fermented dairy food and CVD risk. Brit J Nutr 113: S131-S135

7. Soedamah-Muthu SS, Masset G, Verberne L, Geleijnse JM, Brunner EJ (2013) Consumption of dairy products and associations with incident diabetes, CHD and mortality in the Whitehall II study. Brit J Nutr 109: $718-726$
8. Chilton S, Burton J, Reid G (2015) Inclusion of fermented foods in food guides around the world. Nutrients 7: 390-404

9. Borrelli RC, Visconti A, Mennella C, Anese M, Fogliano V (2002) Chemical characterization and antioxidant properties of coffee melanoidins. J Agr Food Chem 50: 6527-6533

10. Snchez-Gonzlez I, Jimnez-Escrig A, Saura-Calixto F (2005) In vitro antioxidant activity of coffees brewed using different procedures (Italian, espresso and filter). Food Chem 90: 133-139

11. Silva CF, Batista LR, Abreu LM, Dias ES, Schwan RF (2008) Succession of bacterial and fungal communities during natural coffee (Coffea arabica) fermentation. Food Microbiol 25: 951-957

12. Kwak HS, Jeong Y, Kim M (2018) Effect of yeast fermentation of green coffee beans on antioxidant activity and consumer acceptability. J Food Quality Volume 2018, Article ID 5967130, 8

13. Kozich JJ, Westcott SL, Baxter NT, Highlander SK, Schloss PD (2013) Development of a dual-index sequencing strategy and curation pipeline for analyzing amplicon sequence data on the MiSeq Illumina sequencing platform. Appl Environ Microbiol 79: 5112-5120

14. Schloss PD, Westcott SL, Ryabin T, Hall JR, Hartmann M, Hollister EB, Lesniewski RA, Oakley BB, Parks DH, Robinson CJ (2009) Introducing mothur: open-source, platform-independent, community-supported software for describing and comparing microbial communities. Appl Environ Microbiol 75: 7537-7541

15. Westcott SL, Schloss PD (2017) OptiClust, an Improved Method for Assigning Amplicon-Based Sequence Data to Operational Taxonomic Units. mSphere 2: e00073-00017

16. Segata N, Izard J, Waldron L, Gevers D, Miropolsky L, Garrett WS, Huttenhower C (2011) Metagenomic biomarker discovery and explanation. Genome Biol 12: R60

17. Holmes I, Harris K, Quince C (2012) Dirichlet multinomial mixtures: generative models for microbial metagenomics. PloS one 7: e30126

18. Douglas GM, Maffei VJ, Zaneveld J, Yurgel SN, Brown JR, Taylor CM, Huttenhower C, Langille MGI (2019) PICRUSt2: An improved and extensible approach for metagenome inference. bioRxiv: 672295

19. White JR, Nagarajan N, Pop M (2009) Statistical methods for detecting differentially abundant features in clinical metagenomic samples. PLOS Comput Biol 5: e1000352

20. Klinder A, Shen Q, Heppel S, Lovegrove JA, Rowland I, Tuohy KM (2016) Impact of increasing fruit and vegetables and flavonoid intake on the human gut microbiota. Food Funct 7: 1788-1796

21. Jiao X, Wang Y, Lin Y, Lang Y, Li E, Zhang X, Zhang Q, Feng Y, Meng X, Li B (2019) Blueberry polyphenols extract as a potential prebiotic with anti-obesity effects on $\mathrm{C} 57 \mathrm{BL} / 6 \mathrm{~J}$ mice by modulating the gut microbiota. J Nutr Biochem 64: 88-100

22. Hjorth MF, Blaedel T, Bendtsen LQ, Lorenzen JK, Holm JB, Kiilerich P, Roager HM, Kristiansen K, Larsen LH, Astrup A (2019) Prevotella-toBacteroides ratio predicts body weight and fat loss success on 24-week diets varying in macronutrient composition and dietary fiber: results from a post-hoc analysis. Int J Obesity (Lond) 43: 149-157

23. Vital M, Karch A, Pieper DH (2017) Colonic Butyrate-Producing Communities in Humans: an Overview Using Omics Data. mSystems 2

24. Louis S, Tappu RM, Damms-Machado A, Huson DH, Bischoff SC (2016) Characterization of the Gut Microbial Community of Obese Patients Following a Weight-Loss Intervention Using Whole Metagenome Shotgun Sequencing. PLoS One 11: e0149564

25. Del Chierico F, Abbatini F, Russo A, Quagliariello A, Reddel S, Capoccia D, Caccamo R, Ginanni Corradini S, Nobili V, De Peppo F, Dallapiccola B, Leonetti F, Silecchia G, Putignani L (2018) Gut Microbiota Markers in Obese Adolescent and Adult Patients: AgeDependent Differential Patterns. Front Microbiol 9: 1210

26. Huhn R, Stoermer H, Klingele B, Bausch E, Fois A, Farnetani M, Di Rocco M, Boue J, Kirk JM, Coleman R, Scherer G (1998) Novel and recurrent tyrosine aminotransferase gene mutations in tyrosinemia type II. Hum Genet 102: 305-313 